\title{
The Agrarian, Structural and Cultural Constraints of Smallholders' Readiness for Sustainability Standards Implementation: The Case of Indonesian Sustainable Palm Oil in East Kalimantan
}

\author{
Arya Hadi Dharmawan ${ }^{1, *} \mathbb{1}$, Dyah Ita Mardiyaningsih ${ }^{2} \mathbb{D}$, Faris Rahmadian ${ }^{2}$, Bayu Eka Yulian ${ }^{1}(\mathbb{D}$, \\ Heru Komarudin ${ }^{3}$, Pablo Pacheco ${ }^{4} \mathbb{D}$, Jaboury Ghazoul ${ }^{5}$ and Rizka Amalia ${ }^{1}$ \\ 1 Department of Communication and Community Development Sciences, Bogor Agricultural University, \\ Bogor 16680, Indonesia; bayueka@apps.ipb.ac.id (B.E.Y.); amalrizka@apps.ipb.ac.id (R.A.) \\ 2 Center for Agricultural and Rural Development Studies, Bogor Agricultural University, \\ Bogor 16680, Indonesia; dyahita@apps.ipb.ac.id (D.I.M.); faris_rahmadian@apps.ipb.ac.id (F.R.) \\ 3 Center for International Forestry Research (CIFOR), Bogor 16115, Indonesia; h.komarudin@cgiar.org \\ 4 World Wildlife Fund (WWF), Washington, DC 20037, USA; Pablo.Pacheco@wwf.org \\ 5 Department of Environmental Systems Science, ETH Zurich, 8092 Zurich, Switzerland; \\ jaboury.ghazoul@env.ethz.ch \\ * Correspondence: adharma@apps.ipb.ac.id
}

check for updates

Citation: Dharmawan, A.H.;

Mardiyaningsih, D.I.; Rahmadian, F.; Yulian, B.E.; Komarudin, H.; Pacheco, P.; Ghazoul, J.; Amalia, R. The Agrarian, Structural and Cultural Constraints of Smallholders'

Readiness for Sustainability Standards Implementation: The Case of Indonesian Sustainable Palm Oil in East Kalimantan. Sustainability 2021, 13, 2611. https://doi.org/10.3390/ su13052611

Academic Editor: Antonio Ledda

Received: 22 January 2021

Accepted: 19 February 2021

Published: 1 March 2021

Publisher's Note: MDPI stays neutral with regard to jurisdictional claims in published maps and institutional affiliations.

Copyright: (c) 2021 by the authors. Licensee MDPI, Basel, Switzerland. This article is an open access article distributed under the terms and conditions of the Creative Commons Attribution (CC BY) license (https:// creativecommons.org/licenses/by/ $4.0 /)$.

\begin{abstract}
The expansion of oil palm plantation has caused adverse impacts on the ecosystem. It has been associated with deforestation, biodiversity loss, disturbances to environmental services and livelihood change. The government of Indonesia has made an effort to control the negative effects by issuing relevant policies. One of the policies is Indonesian Sustainable Palm Oil (ISPO)'s sustainability standards to which large-scale plantations and smallholders are obliged to adhere. This study assesses the readiness of two types of smallholders, namely, the nucleus-plasma scheme and independent smallholders to adopt ISPO standards. Using a case study research approach in two oil palm plantation villages in East Kalimantan, the study found out a number of ISPO implementation challenges, grouped into structural and socio-cultural challenges, which make smallholders less ready to adhere to this mandatory policy. Coping with these challenges, this study proposed that land and business legality programs be expedited to strengthen property rights, and that training and education programs be intensified to enhance awareness, knowledge and capacity of smallholders to enable them to comply with sustainability standards.
\end{abstract}

Keywords: oil palm expansion; smallholders; governance; sustainability standards; ISPO

\section{Introduction \\ 1.1. Background \\ 1.1.1. Palm Oil as Flex Crop}

Oil palm is a flex crop that can be used as food, feed, fuel, or as an industrial material. The cultivation system of oil palm is more efficient, making it have a higher competitive advantage than other commodities such as soybeans and rapeseed. Its high productivity and lower cost of cultivation bring substantial and attractive benefits either at micro business unit or at macro-economic system [1,2].

Palm oil generates significant added value in the economy and in creating employment opportunities, as well as boosting regional economic development. For the case of Indonesia, export values of palm oil amounted to USD 23 billion in 2017 [3]. Palm oils, produced either for domestic uses or global markets, satisfy the needs of food industry, cooking oil, and bio-energy industries.

Oil palm economy also promises well-being as well as positive impacts on the dynamics of rural economies at local levels [4]. It also generates socio-economic benefits to 
local communities, increasing incomes among households [5,6]. Communities engaging in plantations enable them to increase their consumption capacity, food and non-food expenditures, and to provide farming households' business with substantial economic benefit and saving $[5,7]$. Oil palm is also widely cultivated by local communities in many forms of production organizations, enabling them to keep adapting to the local context and the changing economy $[8,9]$. These organizations strongly integrate local people with the large-scale economy of oil palm companies [6,8]. Oil palm plantations provide women with opportunities to work in the oil palm industry [10].

\subsubsection{The Risks of Expanding Oil Palm Plantation}

The expansion of oil palm plantations has become increasingly criticized as it is strongly associated with ecological and social risks. Its large-scale and monoculture pattern of cultivation is assumed to change ecological landscapes [11,12] and land cover, especially in previously forested areas [13], and to cause habitat losses [14,15]. Oil palm plantations are assumed to trigger habitat fragmentation of various species, resulting in biodiversity losses [16]. Moreover, oil palm plantations are also accused of causing carbon emissions from forests $[17,18]$, decreasing capacity of environmental services $[19,20]$, and causing water pollution [21].

People's heavily dependence on this crop tends also to make income from oil palm a single source [22], which potentially causes them to become vulnerable in case of serious income disruption $[6,23]$. There are also changes in local community livelihood from subsistence to become more dependent on market-oriented economy, widening the gap in social inequality among different social strata [24]. Serious conflicts are also reported to occur among farming households or between farming households and plantation companies. Agrarian conflicts occurred between smallholders, who allegedly encroached land expansively within national park zones, and the park managers [19,25]. Some cases involve indigenous people struggling for control of their ancestral lands under customary land rights [26]. Increased pressures on lands and illegal land acquisition or grabbing exacerbate weak governance of the sector, damaging the credibility of overall oil palm plantations particularly in Indonesia [27,28].

\subsubsection{Certification as a Measure to Contain Negative Effects of Plantations}

Sustainability standard certification is thought to ensure sustainable production and processing of palm oil and to avoid negative effects while improving the governance of the sector. Palm fruit fresh bunches and oils produced from production and industry processing units are certified sustainable once they have been assessed and verified against a set of sustainability principles and criteria. This set of standards generally covers land and business legality, good agricultural practices, community respect and human rights, environmental or ecosystem management, and sustainable business. Certified palm oils play a role in reducing greenhouse gas emissions [29] but palm oil certification has also been strongly criticized as it profits more the global north trade [30].

Indonesian Sustainable Palm Oil, or so-called ISPO, which will be the main focus of this paper, is claimed to be one of certification schemes that are mandatory for all growers, including smallholders. The mandatory scheme, which is a government policy, is argued to have emerged as a result of transformation in the governance and negotiations among key actors involved in the palm oil sector [31]. As of January 2021, of the total 763 issued ISPO certificates, smallholders joining in cooperatives, village unit cooperatives, farmer group or association are found to account for only $2.75 \%$ or 21 certificates [32].

This paper focuses on how ISPO has been implemented at smallholder or farming household level. Despite the increasing role of smallholders in contributing to the national plantation areas and production, they continue to encounter critical issues. There are differences in how different types of smallholders adapt to the need for certification standards [33], and there is a need to understand socio-ecological background before smallholders are willing to participate in the scheme [34]. Challenges facing smallholders are 
concerned with structural constraints hindering them to conform with ISPO sustainability principles, and with socio-cultural hurdles limiting their participation. Most of smallholders hold a view that farming must be regarded as way of living rather as a business unit to gain market benefit.

For smallholders, sustainability is something that is very complicated to achieve. Having a very small piece of land of low productivity, smallholders are motivated to increase production and income by expanding their plantations, often allegedly encroaching forest areas. Deforestation has then become an issue. Despite the detrimental effect on land and forest, territorial expansion is the one only pathway to guarantee increasing standard of living. Sustainability is rather neglected due to increasing demands for achieving better livelihood and welfare status [35]. Such a livelihood strategy is difficult for consumers from developed countries to understand who hold the principle of sustainable consumption. The standard should be applied from farming activities till the end consumption. This is called the "farm to fork" principle. For most smallholders, oil palm sustainability certification may be meant as a process of intentional impoverishment and livelihood limitation, due to the fact that their livelihood space is strictly constrained [36]. Sustainability certification is absolutely necessary to ensure no deforestation in oil palm production. The meaning of sustainability, which has different understanding between oil palm smallholders and end consumers, makes it difficult for the process of certification in the locality [37].

\subsection{Problem Statement}

\subsubsection{Palm Oil Certification as Socio-Ecological Risk Mitigation}

The issuance of ISPO is primarily intended to mitigate socio-ecological risks resulting from oil palm production and processing. Unlike private governance system, ISPO as a state-promoted governance system [38] is basically an institutional instrument to control management of production system so as to ensure that agreed standards are completely met when producing commodities for public consumption [39]. ISPO certification, coupled with traceability systems, aims at ensuring that palm oils are produced in a sustainable manner in both upstream production and downstream processing. More specifically, ISPO principles and criteria guide growers to establish plantations in legal and zones already allocated for plantations, adopt good agriculture practices (e.g., certified seeds), avoid using fire for land clearing, set aside high-conservation areas and plan environment management and monitoring. Additionally, growers have also to respect community rights, establish equal partnerships with, and empower, nearby communities, and provide labor with decent facilities.

Once these principles and criteria are adhered to, consistently enforced, and implemented routinely, it is very likely that their practice would lead to reduced forest land conversion, ensure less pollution, and less social conflicts at the locality level. Certification goes beyond simply achieving legal requirements for oil palm business units [40]. Sustainability certification is also meant to guarantee the realization of good agricultural practices which are important for the end consumer in ensuring sustainable food consumption. Sustainability certification is expected to effectively work as a limiting institution for both large companies and smallholders so that their operation guarantees minimum level of negative risks either socially or environmentally [35,41].

Nevertheless, how far can the implementation of a sustainable governance system run effectively as expected? As is the case with the implementation of the private governance of palm oil RSPO (Roundtable Sustainable Palm Oil), ISPO also received a lot of sharp criticism in its application in the field. The question arises, is it true that sustainability goals can be achieved easily through ISPO certification process, especially for small-scale farmers or smallholders?

\subsubsection{Barrier to Sustainability Standard Adoption}

Smallholders are found to have a difficulty in completely understanding and participating in sustainability certification schemes including ISPO [42]. This is due to the fact that 
smallholders mostly face weak knowledge infrastructure and lack access to information, which would enable them to increase awareness of sustainability practices and general knowledge of sustainability. Weak technical capacity and inadequate finance have also prevented them from engaging in certification programs. Some research indicated that most of the small-scale farmers are not aware that certification will have positive impact on good governance and therefore it potentially generates economic incentives. The incentive should be viewed in the sense that by having the certificate of sustainability, the products will more easily penetrate the international palm oil market [36]. Other challenges, which will be discussed and confirmed further in the Discussion section, include insecure property rights, complicated bureaucracy, no premium price and lack of collective actions.

\section{Materials and Methods}

This article is presented based on empirical research conducted in two villages in Kutai Kartanegara Regency, East Kalimantan Province, Indonesia. Two villages, namely, (1) Muara Kaman Ulu (MKU) in Muara Kaman Sub-District and (2) Jonggon (JGN) in Loa Kulu Sub-District, are chosen as samples. These two locations were chosen because they represent two types of smallholder oil palm plantations: schemed and independent smallholders. Smallholders in Muara Kaman Ulu Village are formally organized under the Muara Kaman Ulu Bina Tani (BTMU) cooperative. The BTMU cooperative has a role in facilitating smallholders' participation not only in managing palm oil farm production but also in communicating its members' aspirations and engaging in business transactions with oil palm companies. The cooperative is entered into an agreement with nearby companies in a nucleus-plasma partnership. Under such a partnership scheme, the BTMU cooperative regularly supplies fresh fruit bunches (FFBs) produced by its smallholders as plasma to the company as nucleus. The FFBs from the plasma are then transported to the processing mills owned by the nucleus, which will further process and produce crude palm oil (CPO). The CPO from the nucleus is then sent or sold to refineries or next processing unit plants to produce cooking oils or biodiesel, which could belong to its parent company or other traders. Smallholders of the JGN Village manage their plantations independently, relying day-to-day management on household labor. They are not committed to any nucleusplasma arrangement. They sell the FFB directly to local wholesalers or middlemen who are normally connected to and have transactional deals with particular company's CPO processing mills. When the research was conducted, ISPO was only mandatory for company growers but not smallholders. However, as these two smallholders, to a certain degree, become part of palm oil supply chains, they are subject to ISPO standard adoption.

To obtain data and information, this research uses a mixed method that combines qualitative and quantitative approaches. A qualitative approach with a case study strategy using in-depth interviews with several key informants was implemented in each study location. Key informants were selected from village-community leaders who had sufficient knowledge of each single farming household dealing with oil palm as well as the history of oil palm plantation development in each location. Meanwhile, a quantitative approach using a survey method drew 35 units of farming household for each location (village) as samples. This survey method was mainly used to obtain data at the level of household. Primary data were used to measure readiness of both types of oil palm smallholders in the implementation of ISPO certification. The fieldwork study for obtaining quantitative and qualitative data was conducted during the years of 2017-2018.

The readiness of independent and nucleus-plasma scheme oil palm smallholders in implementing ISPO certification was measured by using gap analysis method, so-called Importance Performance Analysis (IPA). In assessing people's perceptions on actual and ideal attributes of the ISPO principles and criteria, interviews were carried out with selected respondents representing smallholders of $M K U$ Village (nucleus-plasma-schemed oil palm smallholders) and JGN villages (independent oil palm smallholders). They were asked to respond to a series of questions on various attributes and indicators derived from 12 criteria as presented in Table 1. A value is given in a scale between one to four (1-4) for each 
attribute or indicator where 1 (one) represents the lowest level of importance and 4 (four) denotes the highest level of importance. Two types of assessments were applied, i.e., assessment for actual condition ("what is") and assessment for ideal or expected condition ("what should"). By measuring IPA on a scale of 1-4, the study was able to map out the level of readiness or the effectiveness of ISPO at the smallholders' level (Table 1).

Data generated from IPA are not only used to produce ISPO implementation readiness index values, but also to develop a strategy to improve the readiness of target actors in fulfilling each ISPO attribute. Employing four quadrants, each with distinct performance improvement values: "ideal for certification" (Quadrant I), "easy-to-do improvement" (Quadrant II), "the most-difficult to do improvement (Quadrant III), and "major priorities for improvement" (Quadrant IV), sheds light on policy measures that can be taken to increase the readiness of smallholders in complying with ISPO standards.

Table 1. Classification of independent smallholder readiness index in Indonesian Sustainable Palm Oil (ISPO) implementation.

\begin{tabular}{ccc}
\hline Readiness Level & $\begin{array}{c}\text { IPA (Importance Performance } \\
\text { Analysis) Calculation }\end{array}$ & Readiness Index Value \\
\hline Not Ready & $0.00-0.34$ & $0-34$ \\
Less Ready & $0.35-0.50$ & $35-50$ \\
Fairly Ready & $0.51-0.65$ & $51-65$ \\
Ready & $0.66-0.80$ & $66-80$ \\
Very Ready & $0.81-1.00$ & $81-100$ \\
\hline
\end{tabular}

The use of IPA method has relatively advanced, especially in the fields of marketing, services and tourism [43-46], and its modified use in natural resource management and exploring farmer groups' perceptions on particular policies affecting their livelihood is good. The method has been useful in assessing the level of readiness of independent smallholders in implementing ISPO certification. The IPA index is developed based on ISPO attributes or indicators as presented in Table 2, grouped into 12 criteria and 4 principles. Based on this classification, the higher the index value, the more likely that oil palm smallholders are ready to comply with ISPO policies.

Table 2. ISPO principles and criteria and attributes or indicators against which smallholders' readiness to comply is assessed.

\begin{tabular}{|c|c|c|c|}
\hline ISPO Principles & & ISPO Criteria & ISPO Attributes or Indicators \\
\hline \multirow{5}{*}{$\begin{array}{l}\text { Principle I: Legality } \\
\text { Aspects of the } \\
\text { Smallholders }\end{array}$} & \multirow{3}{*}{ A. } & \multirow{3}{*}{ Land legality } & $\begin{array}{l}\text { Degree of smallholders' knowledge on the procedure and } \\
\text { requirements for land permit. }\end{array}$ \\
\hline & & & Degree of smallholders' knowledge on their own land status. \\
\hline & & & $\begin{array}{l}\text { Degree of understanding among smallholders of information } \\
\text { regarding land status and boundaries and state forest zonation } \\
\text { provided by governments agencies. }\end{array}$ \\
\hline & \multirow{2}{*}{ B. } & \multirow{2}{*}{ Business registration } & $\begin{array}{l}\text { Degree of smallholders' knowledge on the procedure for } \\
\text { obtaining Surat Tanda Daftar Budidaya }(\text { STDB) or plantation } \\
\text { registration letters. }\end{array}$ \\
\hline & & & $\begin{array}{l}\text { b. Degree of understanding among smallholders of information on } \\
\text { the procedure for obtaining } S T B D \text { provided by } \\
\text { government agencies. }\end{array}$ \\
\hline
\end{tabular}


Table 2. Cont

\begin{tabular}{|c|c|c|c|}
\hline ISPO Principles & & ISPO Criteria & ISPO Attributes or Indicators \\
\hline \multirow{13}{*}{$\begin{array}{l}\text { Principle II: } \\
\text { Smallholder } \\
\text { Organization and } \\
\text { Management }\end{array}$} & \multirow{3}{*}{ C. } & \multirow{3}{*}{$\begin{array}{l}\text { Independent smallholder } \\
\text { organizations }\end{array}$} & $\begin{array}{l}\text { Degree of smallholders' knowledge on how to establish and to } \\
\text { organizationally run farmers-group or cooperatives. }\end{array}$ \\
\hline & & & $\begin{array}{l}\text { Degree of smallholders' participation in farmers-group or } \\
\text { cooperatives. }\end{array}$ \\
\hline & & & $\begin{array}{l}\text { Benefit that may be acquired by smallholders participating in the } \\
\text { farmers-group or cooperative especially in the management of oil } \\
\text { palm plantations. }\end{array}$ \\
\hline & D. & Plantation management & The availability of documents on plantation operational activity plan. \\
\hline & \multirow{3}{*}{ E. } & \multirow{3}{*}{ Land dispute resolution } & $\begin{array}{l}\text { a. Degree of smallholders' knowledge on identifying the status of } \\
\text { lands that may potentially be locked in a land-dispute. }\end{array}$ \\
\hline & & & $\begin{array}{l}\text { b. Degree of smallholders' knowledge on identifying the area of } \\
\text { smallholders' already-owned land that may be locked in a } \\
\text { land-dispute issue. }\end{array}$ \\
\hline & & & $\begin{array}{l}\text { c. Degree of smallholders' knowledge on finding out land } \\
\text { dispute resolution. }\end{array}$ \\
\hline & F. & Information transparency & $\begin{array}{l}\text { The smallholders' fulfillment of requested data regarding information } \\
\text { on plantation management system from outside parties. }\end{array}$ \\
\hline & \multirow{5}{*}{ G. } & \multirow{5}{*}{$\begin{array}{l}\text { Good agricultural } \\
\text { practices }\end{array}$} & a. The frequency of land clearing without burning. \\
\hline & & & The use of certified seeds or seedlings. \\
\hline & & & $\begin{array}{l}\text { The use of standard operating procedures and instructions in } \\
\text { farm management. }\end{array}$ \\
\hline & & & $\begin{array}{l}\text { d. The use of integrated pest management technical guidelines in } \\
\text { the field. }\end{array}$ \\
\hline & & & Time precision on fruit harvesting by smallholders. \\
\hline \multirow{8}{*}{$\begin{array}{l}\text { Principle III: } \\
\text { Environmental } \\
\text { Management and } \\
\text { Monitoring }\end{array}$} & \multirow{4}{*}{ H. } & \multirow{4}{*}{ Fire mitigation } & $\begin{array}{l}\text { a. Degree of smallholders' knowledge on the existence of Kelompok } \\
\text { Tani Peduli Api (KTPA) or Masyarakat Peduli Api (MPA)_Fire } \\
\text { Concerned Farmers Group or Fire Concerned Local } \\
\text { Community Organization. }\end{array}$ \\
\hline & & & The prevalence of fires occurting in the oil palm plantation. \\
\hline & & & $\begin{array}{l}\text { c. The frequency of information dissemination regarding the use of } \\
\text { Pembukaan Lahan Tanpa Bakar (PLTB) or non-fire land } \\
\text { clearing technique. }\end{array}$ \\
\hline & & & $\begin{array}{l}\text { The large number of material and equipment support that is } \\
\text { available for PLTB. }\end{array}$ \\
\hline & \multirow{4}{*}{$\mathrm{I}$. } & \multirow{4}{*}{ Biodiversity conservation } & $\begin{array}{l}\text { a. The extent of owned-land area for palm oil that overlaps with the } \\
\text { protected areas. }\end{array}$ \\
\hline & & & $\begin{array}{l}\text { b. The degree of smallholders' participation in } \\
\text { conservation activities. }\end{array}$ \\
\hline & & & $\begin{array}{l}\text { Degree of smallholders' knowledge about the large number of } \\
\text { fauna species existing in the area. }\end{array}$ \\
\hline & & & $\begin{array}{l}\text { d. Degree of smallholders' knowledge about the large number of } \\
\text { animals existing in the area. }\end{array}$ \\
\hline
\end{tabular}


Table 2. Cont.

\begin{tabular}{|c|c|c|c|}
\hline ISPO Principles & & ISPO Criteria & ISPO Attributes or Indicators \\
\hline \multirow{9}{*}{$\begin{array}{l}\text { Principle IV: } \\
\text { Improvement on } \\
\text { Business and } \\
\text { Sustainability }\end{array}$} & $\mathrm{J}$ & Productions potentiality & $\begin{array}{l}\text { The potentiality for increasing sustainable palm oil production in } \\
\text { the region. }\end{array}$ \\
\hline & \multirow{6}{*}{$\mathrm{K}}$. & \multirow{6}{*}{$\begin{array}{l}\text { Constraints to increase } \\
\text { productivity }\end{array}$} & a. Quality of production \\
\hline & & & b. Land quality \\
\hline & & & c. Large extent of land area \\
\hline & & & d. Quality of human resources \\
\hline & & & e. Technological quality \\
\hline & & & f. $\quad$ Marketing \\
\hline & & \multirow{2}{*}{$\begin{array}{l}\text { Effort to increase } \\
\text { productivity }\end{array}$} & a. Extensification \\
\hline & & & b. Intensification \\
\hline
\end{tabular}

Source: Modified from the Annex to the Draft Regulation of the Minister of Agriculture of the Republic of Indonesia on Principles and Criteria for Indonesian Sustainable Oil Palm Plantations (ISPO) for Growers (2017).

\section{Results}

\subsection{Types of Farming Production Organizations}

The extent to which schemed and independent smallholders are effectively complying with ISPO principles and criteria in managing their plantations is affected by the characteristics of rural socio-economic system and policy directions coming from the outside system. This is reflected by the two smallholder communities under study.

MKU is an oil palm plantation village which has a long settlement history around the Kedang Rantau River; the social structure of its community is strongly marked by the Kutai Melayu community. The rural livelihoods are mostly dependent on oil palm and fishing activities either for subsistence needs or for generating incomes. Oil palm areas are usually located separately from the settlement. $M K U$ Village is physically dominated by peat swamp ecosystem leaving only a small part of land for agriculture. MKU Village has a long history related to the oldest Hindu tradition in the archipelago from Kutai Martadipura. The economy of $M K U$ Village was largely affected by the presence of two large-scale oil palm plantation corporations (namely, PT. SKL and PT. PMM) that have been operating since 2006. With such a socio-cultural and economic background, MKU Village is a relatively progressive rural society.

On the other hand, JGN Village is a clustered rural settlement in a specific area where the location was evolved through transmigration program by the government. The social structure of the community is dominated by the Javanese people (transmigrants) who lived next to the indigenous Dayak Basap people. The people of JGN Village maintain their livelihood from small-scale agricultural activities. Oil palm has been a major source of income and activity of $J G N$ rural households since land is predominantly upland. The majority of lands for farming are separated into two places. Each farming household controls more or less two hectares of land for oil palm plantation on average.

There is a difference between the smallholders of $M K U$ and JGN in their type of organization of production. Most of the farming households of JGN Village are independent smallholders who run the plantation freely and sell the FFB wherever they like without having to be tied to a particular $\mathrm{CPO}$ milling factory. The smallholders can choose any wholesaler who provides the highest price of the FFB. On the contrary, the smallholders of $M K U$ Village are tied to nucleus-plasma scheme organization of production making them not free to sell the FFB. They have very limited space to move freely because they are bound by a number of production agreements with the nucleus (the large-scale company). 


\subsection{The Readiness Level of Smallholders to Implement ISPO Certification}

\subsubsection{Index of Readiness for ISPO Certification}

The issuance of ISPO policy is partly driven by increased public environment awareness and motive to limit socio-ecological risks arising from palm oil plantation expansion and unsustainable production of palm that cause deforestation, and to ensure green growth $[47,48]$. The Indonesian government sees ISPO as an important instrument not only to develop sustainable supply chains of palm oil and meet international market recognition, but also to improve the governance of the oil palm sector. Considering its importance, the government recently changed the legal basis for ISPO to a higher level of laws, from previously agricultural ministerial regulation No. 11/2015 to a presidential regulation No. 44/2020, making it more legally binding and enforced.

It remains to be seen how this new regulation will affect the level of compliance among actors with the new standard. However, studies predicted that land and business legality issues, e.g., lack of certified seedlings, would continue to hinder the effective implementation of ISPO [9,33]. In most cases, oil palm smallholders across many regions face difficulties to comply with ISPO standards. They also lacked capacity to adopt environmental management practices and to establish and manage farmer organizations. All of these major issues also apply to smallholders of MKU Village and JGN Village and made sustainability difficult to achieve.

Based on the IPA analysis using the four principles of ISPO certification (Table 1), the nucleus-plasma-schemed oil palm smallholders of $M K U$ has a total index value of 60 , meaning that they are relatively/fairly ready for going through ISPO sustainability verification processes. Though this level was still low with regard to reaching the ready level, which is in the range of readiness values 66-80. Independent oil palm smallholders of JGN Village showed a much lower level of readiness to implement ISPO, in which their total index value was 50. They are insufficiently capable of meeting many attributes or indicators of ISPO.

The 12 values as results of assessment are presented in Figure 1, showing various gaps between what is happening (actually) in reality and what should expectedly (ideally) be achieved. The wider the gap between the actual and ideal values indicates the greater the chance that respective smallholders are unprepared to understand, follow and comply with ISPO attributes or indicators. Figure 1 found a similar pattern of readiness between smallholders of $M K U$ Village and JGN Village to adopt ISPO. It particularly applies to most social and economic aspects of ISPO. There is a relatively better level of preparedness and willingness of both smallholders to (1) independently organize farming organizations, (2) resolve arising land disputes, (3) implement good agricultural practices, (4) increase crop production and (5) handle the constraining factors of productivity, and finally (6) make efforts to increase productivity.

However, most of the smallholders were not ready yet to cope with issues around agrarian and environment aspects. Figure 1 showed that a gap between actual and ideal values regarding these aspects is too wide, indicating that their readiness is too low. They mostly have problems with legal documentation and basis for their lands and planting business. They do not (1) own land certificate to secure their land nor (2) hold planting business registration. Additionally, they also (3) lack capacity to manage their plantations according to good agriculture practices, (4) are less aware and informed of information on plantation management, and (5) are less prepared to take mitigation actions in the event of fire or burning occurring in their plantations. There is also general indication among all smallholders that they (6) slightly lack commitment or readiness to take measures to conserve biodiversity. 


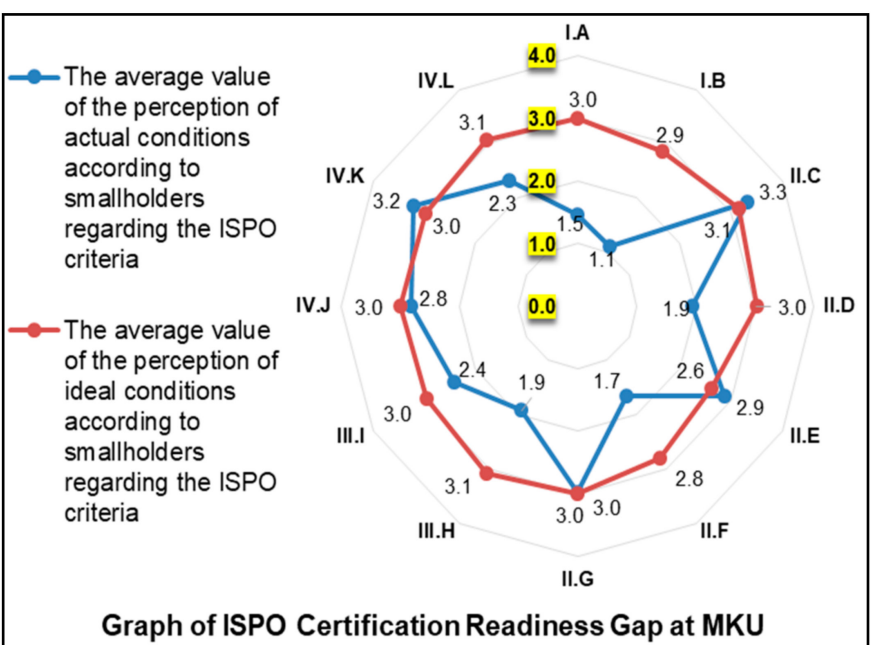

Graph of ISPO Certification Readiness Gap at MKU

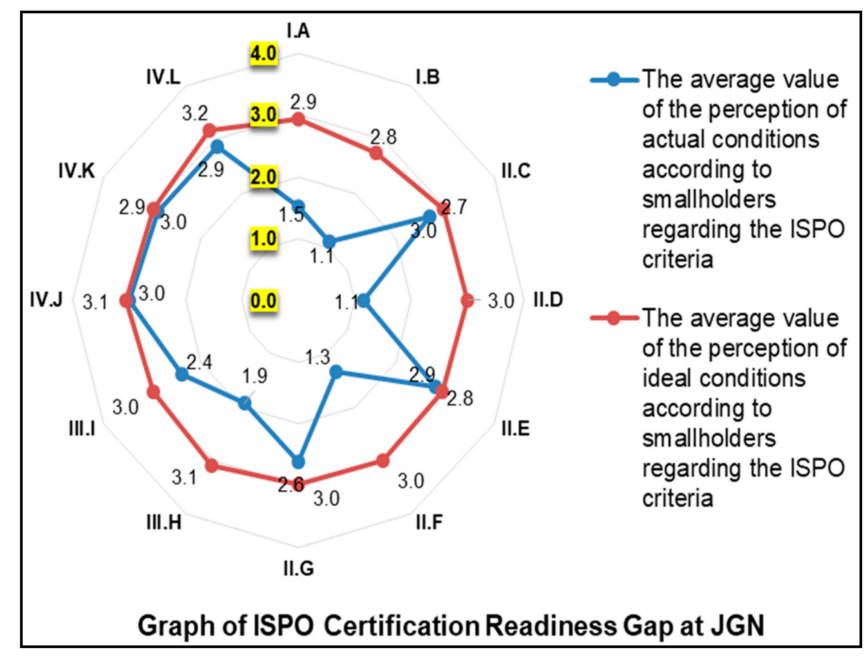

Note:

I.A. Land legality

I.B. Business license

II.C. Independent smallholder

II.D. Plantation management

Sources: primary data (2018)

\author{
II.E. Land dispute resolution \\ II.F. Information transparency \\ II.G. Good Agricultural Practices \\ III.H. Fire mitigation
}

\author{
III.I. Biodiversity conservation \\ IV.J. Productions potentiality \\ IV.K. Constraints to increase productivity \\ IV.L. Effort to increase producttivity
}

Figure 1. Gap of ISPO certification readiness according to smallholders' objectivity towards certification criteria in Muara Kaman Ulu (MKU) Village and Jonggon (JGN) Village, 2018.

So far, three conclusions may be drawn from this IPA analysis, as follows:

1. There was no significant difference between nucleus-plasma scheme of oil palm smallholders and independent oil palm smallholders in their readiness for ISPO certification;

2. Both types of smallholders' organization of production showed the same reaction to the ISPO certification, where they were responsive to economic aspects;

3. Both types of smallholders did not show any positive preparedness of ISPO certification for agrarian and environmental aspects. In general, it could be said that the readiness of both types smallholders for achieving oil palm sustainability via ISPO parameters was very low.

These three points make it less possible for the smallholders from any type of organization of production to fully support ISPO certification implementation in the field.

\subsubsection{The Issues of Agrarian and Social-Structural Constraints \\ Land Legality}

Corroborating earlier studies on smallholders and mandatory sustainability [33,49], this study found that lack of land legality documentation is a major issue hindering smallholders to get ready for verification under ISPO certification. Most of the existing smallholders under study were not able to show any formal certificate as a legal basis to prove their land ownership. Nevertheless, land ownership is socially secured and deemed legitimate on the eyes of local communities. In most cases, land tenure systems across rural areas are not based on a formal title ownership. Instead, every member of the community socially recognizes and respects every piece of land as someone's property. It is possible that smallholders' lands could be made legal as long as the lands are located outside state forest zones and have been verified by local authorities to have no legal issues and overlap with others' property rights. It becomes risky when the lands are located within state forest zones, this is despite policy measures-as will be discussed in a later section-to grant local and poor communities with ownership right over lands on state forest zones. The traditional land tenure is not recognized under ISPO to enable smallholders to get certified, 
until it becomes formal or legal. ISPO certification could not be operational due to the absence of formal legal-land documents (see also McCarthy [50]).

Efforts are currently underway to resolve agrarian problems as to illegal smallholder plantations overlapping state forest zones. Overlapping plots are usually excluded from the ISPO certification process, because they are regarded as illegal. If this is not resolved, the ISPO standard-moreover the new ISPO regulation that is mandatory for smallholdersmight be seen as a disincentive mechanism that drives smallholders to continue doing illegal business, as oil palm constitutes the major livelihood source for income. It is important to look deeper into different typologies of schemed and independent smallholders under study in order to get a sense of their readiness to adopt ISPO from the land legality aspect. In other regions in Kalimantan, smallholder groups with relatively large areas of plantations, and that are better resourced, tend to clear forests-allegedly on state forest zones-to pave the way for their plantations [33].

\section{Planting Business Registration (STDB)}

ISPO requires that smallholder plantations be registered, geographically mapped and included in the government database. The documentation is referred to as Surat Tanda Daftar Budidaya $(S T D B)$ or a plantation registered letter confirming plantation size and boundaries, owners, planted areas, etc. Based on the regulation, it is actually the responsibility of provincial and district plantation offices to register smallholders occurring in their jurisdiction. However, due to limited resources to collect data on smallholder plantation spreading across extensive areas, these authority tasks are not well performed, as happens in many provinces. Smallholders under study have different reasons as to why they have no $S T D B$, even though this is one requirement before ISPO certification verification can be made. In this regard, STDB was very difficult to arrange due to unpreparedness of the regional of government and the smallholders did not feel that STDB was necessary to fulfill. Some respondents are of the opinion that they are not aware of this requirementwhich can be attributed to the lack of communication by the extension workers. Others express that they are aware that they have to register their plantations, but they are not well informed of a procedure to follow. One respondent who has a better network with external actors, including plantation officers, finds the procedure easy, but simply he has not started to apply.

\section{Farm Organization}

Collective action, farmer group and cooperatives could provide an enabling condition for smallholders to have a stronger bargaining position vis-à-vis other actors, to improve productivity and increase efficiency. Jelsma et al. [51] demonstrate that strong institutional or farmer organizations and successful collective action by palm oil farmers has contributed to comparatively high yields and incomes. Acknowledging the benefits of groups or association, smallholders of either MKU or JGN Village seem to be willing to form farmer groups and combine them into cooperative or farmer organization, as indicated by their readiness to comply with this ISPO requirement. However, independent smallholders in JGN Village are not joined into any farmer groups, nor are they members of nearby cooperatives. It is interesting to note that smallholders in $M K U$ are formally organized in a cooperative, which in theory could benefit from the well-functioned grouping in terms of obtaining updated information on prices and a better price for the sale of FFB. As stated by the respondents, they do not seem to see any difference in becoming a member to the cooperative. They are often not updated on any information on FFB price, planting practices, and they acknowledged lacking organizational skills to run sufficiently a farmer association or cooperative. Building a strong farming association still poses a challenge for those smallholders in both villages. The reasons why independent smallholders in JGN Village and schemed smallholders in $M K U$ are reluctant to join farmer cooperatives—as implicitly expressed by respondents during interviews-are supposedly linked to unpleasant stories about cooperative or farmer groups characterized by internal 
conflicts, poor management and leadership. Due to this institutional, organizational constraint, it will take time for smallholders to organize themselves in workable farmer groups or cooperatives before they are ready for ISPO verification (see also Glasbergen [36]).

\section{Plantation Management}

In both research villages, oil palm development belonging to the smallholders took place very traditionally and informally. Most smallholders learned how to plant from the neighbors. Technical assistance was not available so prominently. It was very rare to find cultivation management practices that were agronomically and technically following standards. Most of the smallholders did not know how to apply standard of soil management, standard of chemical fertilization and pesticides application, or farmland maintenance. Most of them were not aware that legally certified seedlings should be fulfilled. Most of the seedlings were not certified. Smallholders of $M K U$ village were somewhat better because as plasma, their farms received full technical assistance from large-scale companies as the nucleus or their parent business. Nevertheless, their knowledge on good agricultural practices remained less sufficient to support sustainable oil palm cultivation.

\section{Environmental Management}

Environmental issue has been one of big concerns of the international market in questioning the sustainability status of oil palm in tropical regions including Indonesia. Indonesia's palm oil production has long been suspected to cause environmental risks with regard to land use relating to the fact that there exists extensive use of unsuitable land. According to Pirker et al. [48], oil palm has been responsible for arising the problem of biophysical suitability of cultivated land, in which the plantation areas have, in many cases, too many conflicts with forest and protected areas. The peatland areas that have to compromise with oil palm plantations areas were also a big issue. Under such a circumstance, the land has then become susceptible to land fire. Sustainability has been seriously questioned.

ISPO requires schemed, as well as independent, smallholders to demonstrate that they have a letter or Surat Pengelolaan dan Pemantauan Lingkungan (SPPL) declaring the group's commitment to managing and monitoring the environment around their plots. The letter is issued by the district environment office, which is also responsible for overseeing and providing guidance for farmer groups' commitment implementation, particularly in two areas: prevention of fire and biodiversity conservation. Smallholders in the two villages under study seem to be aware of increased incidents of fires-particularly during dry seasons-and concerns about the likely environmental impacts they generate on forests, their plantations and peatlands. Some respondents state that some farmers joined Masyarakat Peduli Api or fire care community, who stand ready to take mitigation efforts to prevent and control fires happening in their villages. Considering the environment concerns, there is increased awareness among some farmers no longer using fire when preparing the lands. This increase in awareness is also due to intense communication made by extension workers on the adoption of no-burn cultivation techniques for preparing lands for establishing plantations or Pembukaan Lahan Tanpa Bakar. Smallholders in two villages are generally aware that the regions where their plantations are located are covered mostly by peat which is vulnerable to fires. The two village farmers' awareness of not using fire is associated with their concern on possible impacts locally on their land and internationally on haze generated from the fire incidents.

Despite this, their lack of preparedness to take mitigation actions in the event of fire as indicated by this study relates to the lack of equipment and resources required to prevent and control fire, and lack of early warning system that would enable them to react immediately to any fire. There is also a general indication that most smallholders under study lack technical capacity to put good environmental management into practice. Lack of technical guidance and assistance from the government extension workers could be an area for improvement in the future. The low commitment or readiness on the part of farmers to 
conserve biodiversity, as indicated by this study, has increased due to rare opportunities for farmers to participate in relevant measures to protect threatened species, not because of their negligence in taking care of key animal and plant species.

\section{Socio-Cultural Constraints}

The analysis of socio-cultural problem facing the readiness of ISPO certification covers three aspects: (1) the problems of lack of cultural character of the smallholders necessary to support progressive and sustainable business operation; (2) the ethics of pragmatism in the oil palm supply chain complex; (3) the culture of farming of the smallholders.

Ethics of Subsistence

One of the critical problems faced by smallholders of $M K U$ and JGN Village was the absence of business character to organize, to manage and to operate unit business necessary to achieve high level of productivity and efficiency of production. The ethics of production was more following subsistence principle, where no target of production was applied and dependency on nature was quite high. Oil palm smallholders did not focus only on single farming activity but rather on multiple farming of many sideline activities. The oil palm smallholding business was not set up to operate and anticipate any financial risks that could hamper production any time. Generally speaking, the oil palm smallholding operation was not set to provide an adequate basis for achieving sustainable operation of palm oil production.

Ethics of Pragmatism

The problem of rationality faced by smallholders of MKU and JGN Villages was fundamentally in relation to the attitude of "pragmatism of business management" in running oil palm operation. This problem was particularly faced by most of the independent smallholders of JGN Village, which the orientation of production was solely taking economic benefits by ignoring any other risk or negative externalities. Most of the smallholders of JGN Village tended to have more self-determination to expand their oil palm plantation (both legally and/or illegally), since they were in a greater position to access multiple choices of market for their FFB. Here, there was an availability of various market options (middlemen or wholesaler). Usually the middlemen or wholesaler did the buying and selling of FFB without questioning where the FFB comes from. They did not pay attention about to the legality of the FFB's places of origin. Unsustainability and illegality were not important issues for the wholesaler or middlemen. Profit was the first consideration as long as there still existed milling factories which accepted the FFB that operated in adjacent locations. For the smallholders, three reasons why middlemen were so important were (1) ease of sales; (2) ease of payment (cash and carry); (3) more accessible location of transaction. Generally speaking, as long as there is still present a black market in the supply chain that smallholders can comfortably refer to the middlemen to simply buy and sell FFB, at the moment sustainability can never be guaranteed to exist. In other words, this attitude of smallholders has made ISPO certification difficult to achieve.

\section{The Culture of Farming}

The culture of farming is the entire picture of agricultural practices shown by smallholders in relation to resources organization of plots of land for oil palm plantation. In this regard, MKU Village and JGN Village had their own particular challenges. In this case, smallholders in $M K U$ Village had more advantages because they were closely and tightly linked to a partnership of nucleus-plasma scheme with companies. Their lands were fully managed by smallholder cooperatives, which had a certain operation of production and land management agreement with the companies (Table 3). 
Table 3. Characteristics of farming culture of smallholders of MKU Village and JGN Village, 2018.

\begin{tabular}{|c|c|c|c|}
\hline No & Characteristic & MKU Village & JGN Village \\
\hline 1 & Origin of land & - $\quad$ Ancestral land & $\begin{array}{l}\text { - } \quad \text { Ancestral land } \\
\text { - } \quad \text { Transmigrant land from the government } \\
\text { - } \quad \text { Fond from purchase } \\
\quad \text { land }\end{array}$ \\
\hline 2 & Land legal status & $\begin{array}{ll}\text { - } & \text { Local level recognition } \\
\text { (community/customary law) } \\
\text { - } \quad \text { Legal (formal certificate) }\end{array}$ & $\begin{array}{ll}\text { - } & \text { Local level recognition } \\
\text { (community-customary law) } \\
\text { - } \quad \text { Legal (formal certificate) }\end{array}$ \\
\hline 3 & First planting & $>2006$ & $>2010$ \\
\hline 4 & Cooperation scheme & Independent plasma smallholders & - \\
\hline 5 & ISPO certification & - & - \\
\hline 6 & $\begin{array}{l}\text { Degree of integration with } \\
\text { large scale plantation or } \\
\text { company }\end{array}$ & $\begin{array}{l}\text { Company responsible for land clearing, } \\
\text { provision (for seedlings, etc.), technical } \\
\text { guidance, and post-harvest processing }\end{array}$ & $\begin{array}{l}\text { Company as buyer. Smallholders carry out all } \\
\text { activities independently (until the FFB is sold } \\
\text { to middlemen or directly to the company) }\end{array}$ \\
\hline 7 & Smallholder organization & $\begin{array}{l}\text { Strong, because there are cooperatives, } \\
\text { local leaders, and company support }\end{array}$ & $\begin{array}{l}\text { Weak, the group only formed as part of } \\
\text { sponsorship activities }\end{array}$ \\
\hline 8 & FFB marketing patterns & $\begin{array}{l}\text { Cooperative as intermediary between } \\
\text { smallholders and company }\end{array}$ & $\begin{array}{l}\text { Middlemen dominated trading. FFBs are } \\
\text { traded to more than one company }\end{array}$ \\
\hline 9 & Payment/transactions & Monthly payment & Cash and carry \\
\hline 10 & Labor use & Casual labor & Domestic workers and casual labor \\
\hline
\end{tabular}

ISPO certification would be much easier to implement in $M K U$ Village because the lands of the smallholders and their management were totally integrated with the companies. In this case, the companies usually showed better compliance with various applicable government regulations. Thus, almost all companies with their nucleus-plasma smallholders were much easier to meet ISPO implementation requirements. Meanwhile, smallholders of JGN Village would face more barriers on land legality since they manage their own land individually and sporadically without considering any legality aspects and/or good agricultural practices (Table 3).

Based on Table 3, it can be seen that the practical problems of farming culture faced by smallholders in MKU Village and in JGN Village were different. The degree of integration with the company also has an impact on the readiness to implement sustainability certifications standard. Smallholders of $M K U$ Village were more prepared for sustainable oil palm certification since they already formed smallholder cooperatives and were technically supported by the companies. To a limited extent, though it was not enough, smallholders of $M K U$ Village were more acquainted with the legal documents and formality of ISPO certification.

Meanwhile, smallholders in JGN Village were less prepared to do ISPO certification as compared to that of MKU Village. They had to prepare almost from zero to achieve sustainable oil palm plantation practices. A smallholder cooperative was not present. If there was a cooperative in the past, it should be reactivated. On the other hand, smallholders in JGN Village still faced complicated aspects of land legality, especially for plantation land that still overlaps with forest areas.

\section{Discussion: Policy Directions to Improve Smallholders' Readiness for ISPO Certification}

Based on the gap analysis shown in Figure 1, the study tried to investigate subjective perceptions of smallholders concerning 12 ISPO criteria. The focus is directed towards those assessments of criteria which still show a wide gap between the actual or the "what is" and the ideal or the "what should". The policy direction shall be directed towards how 
to close the gap between the "what is" and the "what should" of ISPO criteria. As shown in Figure 2, the study presents four quadrant of policy direction that can be chosen in improving smallholders' readiness performance for ISPO certification. The quadrant is formed by " $x$ axis" consisting average values of smallholders' actual perceptions on ISPO criteria, and "y axis" consisting of average values of smallholders' ideal perceptions on ISPO criteria.

Based on IPA analysis and the use of quadrant analysis, the study is able to figure out which priority of ISPO criteria must be paid more attention to for improving the performance of smallholders' readiness in ISPO certification, both in MKU Village and JGN Village. The quadrant analysis shows that the ideal position of the ISPO criteria of smallholders' readiness for ISPO certification shall be located somewhere in Quadrant I. So as to say, all ISPO criteria that are located in Quadrant II, III, and IV must be directed towards Quadrant I if smallholders' readiness for ISPO certification is to be achieved satisfactorily.

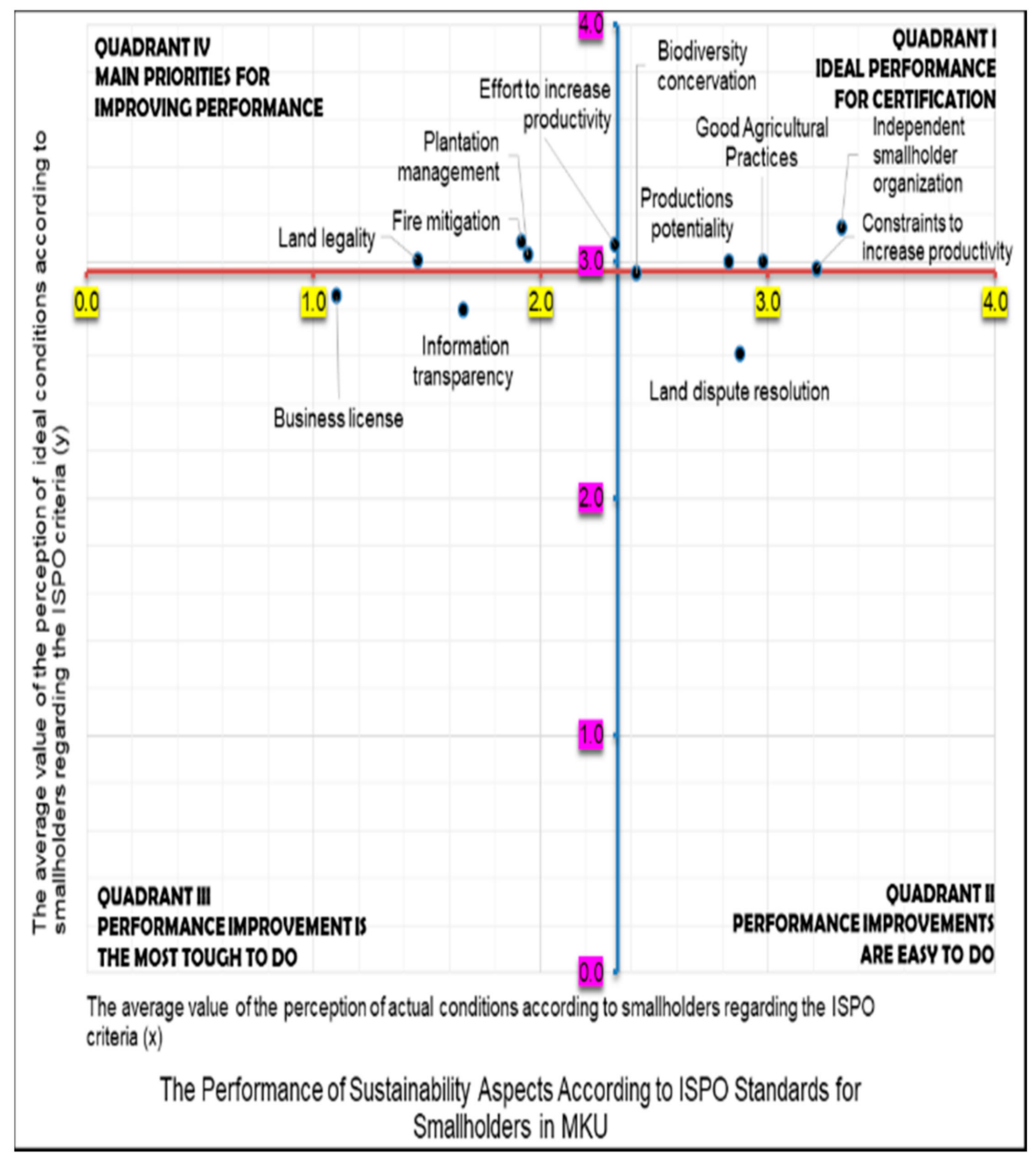

Figure 2. Cont. 


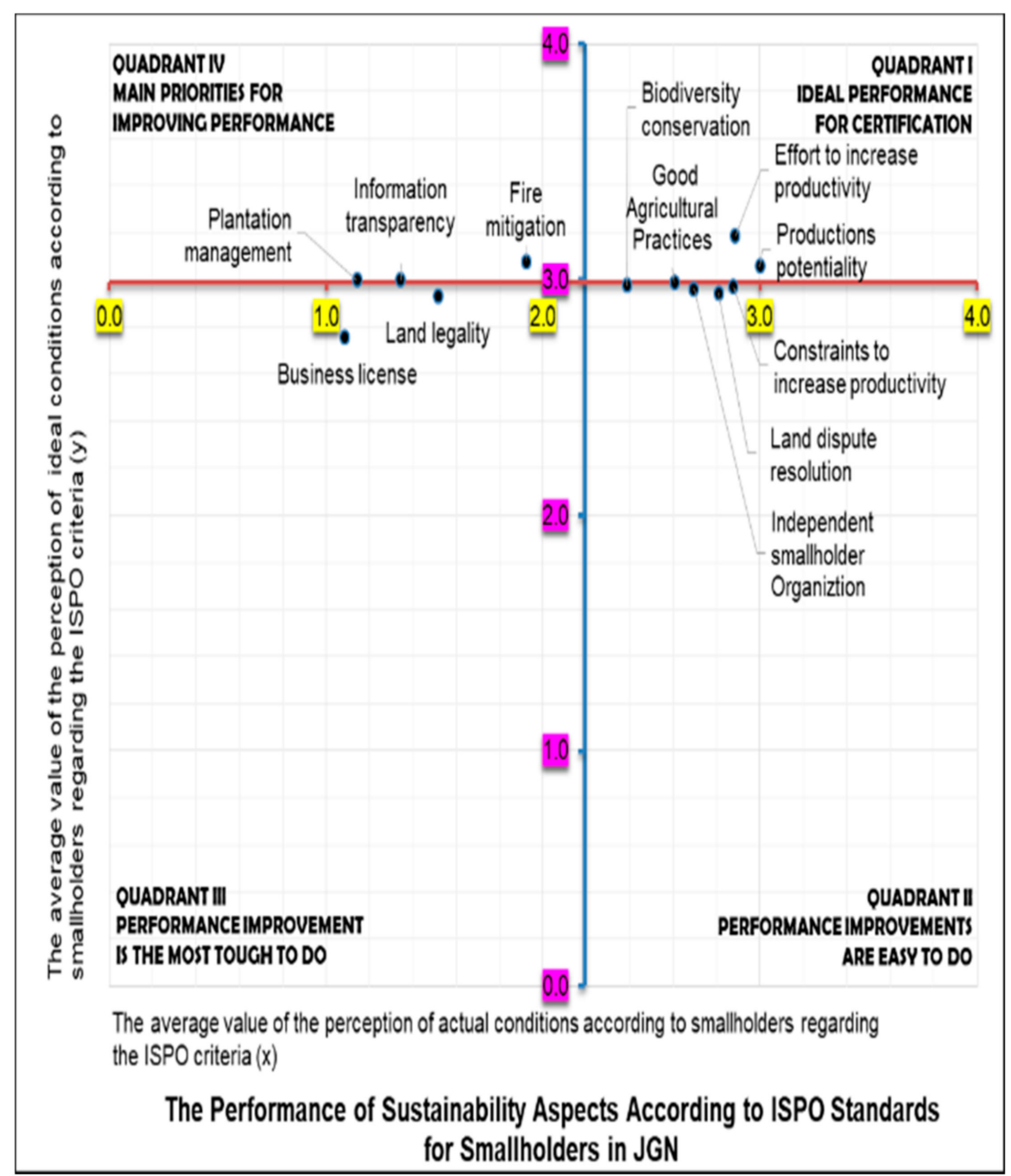

Figure 2. Quadrant of policy direction to increase smallholders' readiness in implementing ISPO certification, in $M K U$ and JGN Village.

Some challenges that constrains smallholders from participating in sustainability certification include:

1. The territorial expansion of oil palm plantation is very often accompanied by forest area encroachment, making the smallholders occupy illegal territory. Being part of illegal landholding has put smallholders in a somewhat complicated situation to follow the sustainability certification program [36]. In such cases, sustainability certification becomes an exclusion mechanism for the smallholders to be excluded from the legal system of oil palm economy.

2. The sustainability certification for smallholders faces the burden of bureaucracy issues, especially at the provincial and district government levels. Local governments do not have sufficient administrative capacity to support the certification process. The magnitude of the challenges has led to skeptical views from smallholders about the immediate economic benefits that may be gained from certification process [35,39].

3. Many smallholders are disappointed by the fact that the certification system cannot guarantee a better price for fresh fruit bunches. Despite being a system that always promises a premium price for certified palm oil, in reality, there is no guarantee of a premium price, because prices follow market fluctuations. This disappointment makes smallholders reluctant to participate in certification programs [42].

4. The certification process does not pay attention to the origin of customary land. The process only focusses on formal land legality that does not respect local customary 
land rights. In other words, compliance with sustainability standards does not necessarily solve problems of agrarian structure in the field [52].

5. Small-scale farmers at any time will not be able to compete with large-scale plantations in accessing the market, without the support of agricultural policies from the government. In particular, there should be clear land policy to support smallholders to rise the livelihood from marginality. In most cases, certification is not a solution to agrarian justice for smallholders unless government land policy intervention is decisive [50].

6. In the field, smallholders are faced with the many choices of certification schemes which often lead them in difficulties to decide which one is better to take up for certification processes [53].

7. It is not easy for most smallholders, with all their knowledge constraints, to run a farmer organization or farmers' association as a prerequisite for certification. Moreover, it is very difficult to expect them to build a new farmer organization without technical assistance from the government [36].

From the above-mentioned issues and challenges, it is reasonable to state that most smallholders face complex challenges in solving related problems to the certification of their oil palm plantation. In other words, it is difficult for them to follow the sustainability standards according to the system of certification (ISPO). This paper tries to find out how prepared the oil palm smallholders from different types of production organizations are to respond to ISPO certification for the sake of achieving sustainability. What policies need to be proposed?

The ISPO criteria that are considered to be the main priority to help improve smallholders' readiness in ISPO certification performance are those which are located in Quadrant IV. These criteria are considered to be much easier to handle. Meanwhile, the ISPO criteria in Quadrant III are the second priority because they are the most difficult to handle. More effort and energy need to be acquired to shift the ISPO criteria from Quadrant III to Quadrant I.

For all ISPO criteria located in Quadrant II, the value is been good. Therefore, there is no need to prioritize all of that criteria to be shifted immediately from Quadrant II. All ISPO criteria located in Quadrant II will be the last priority to be handled rather than those in Quadrants IV and III (see also Table 4).

In both research locations, it is very obvious that improving plantation cultivation management is a top priority to improve performance. This ISPO criteria will have a great impact, particularly on increasing land productivity. Developing a good system of business administration at the smallholder level for cultivation planning, as well as financial flows (payment of labor, purchase of agricultural inputs and sale of FFB), is urgent to do. Information transparency becomes an important issue, especially in JGN Village, due to the absence of good plantation administration. Accordingly, information transparency is still a priority at $J G N$ Village.

Land fires are also still an important environmental issue in both research locations, so they remain a top priority to overcome. At the same time, land legality for MKU Village is a top priority due to the fact that most smallholders do not have any formal land certificates. This is also the case for JGN Village, particularly for smallholders of Dayak tribes where land certificate is usually not common. Last but not least, business registration letter is still a critical issue for smallholders of both research locations. 
Table 4. ISPO criteria priorities for improving the performance of smallholders' readiness for sustainability standards in both research villages.

\begin{tabular}{|c|c|c|}
\hline \multirow{2}{*}{$\begin{array}{l}\text { Quadrant of Policy Direction to Increase Smallholders' } \\
\text { Readiness to Implement ISPO Certification }\end{array}$} & \multicolumn{2}{|c|}{ ISPO Criteria to Improve } \\
\hline & MKU Village & JGN Village \\
\hline Quadrant IV (Main Priorities) & $\begin{array}{ll}\text { - } & \text { Land legality } \\
\text { - } & \text { Plantation management } \\
\text { - } & \text { Fire mitigation } \\
\text { - } & \text { Effort to increase productivity }\end{array}$ & $\begin{array}{ll}\text { - } & \text { Fire mitigation } \\
\text { - } & \text { Information } \\
\text { - } & \text { transparency } \\
\text { Plantation management }\end{array}$ \\
\hline Quadrant III (Second Priorities) & $\begin{array}{ll}\text { - } & \text { Information transparency } \\
\text { - } & \text { Business registration }\end{array}$ & $\begin{array}{ll}\text { - } & \text { Land legality } \\
\text { - } & \text { Business registration }\end{array}$ \\
\hline
\end{tabular}

Based on this analysis, policy measures that can be taken to increase the readiness of smallholders in implementing sustainability standard certification, include:

- Implementing land certification program that is administered by land administration authorities.

- Increasing knowledge capacity of the smallholders in oil palm plantation management through providing training, mentoring and technical assistance.

- Increasing smallholders' awareness of the environmental risks by establishing land fire mitigation group at local level.

- Facilitating the arrangement of plantation business permits and license for all smallholders.

The role of government authorities is very decisive to implement ISPO certification. Central government authorities should work hand in hand with regional and local governments to ensure that all policy measures run well.

\section{Conclusions}

When answering the question on how prepared the oil palm smallholders from different types of production organizations are to implement ISPO certification, the conclusion can be stated as following. There is no significant difference between the readiness of nucleus-plasma-schemed of oil palm smallholders and independent oil palm smallholders in ISPO certification implementation. Both smallholders' organization of production types show similar reaction to ISPO certification, where they are usually very responsive for economic criteria but have a very low response to social and environmental criteria. These types of smallholder organizations of production do not show any strong capacity to prepare for ISPO certification. Two constraints are very obvious to hamper readiness of smallholders for ISPO certification, namely, agrarian and socio-structural factors and socio-cultural factors. These ISPO criteria are still a big issue for smallholders, specifically the absence of land legality, having no business registration letter, lack of capacity in farming organization, and low capacity of environmental and plantation management. These structural factors have made ISPO certification difficult to implement. In addition, ethics of subsistence and ethics of pragmatism in palm oil production and marketing are two factors that play an important role in slowing down individual farming households to prepare ISPO certification. In general, the readiness of smallholders in both types of organization of production is still not supportive for ISPO certification. For almost all ISPO criteria, the readiness of smallholders is still not satisfactorily. Thus, oil palm sustainability is still far from expectation.

To answer the question of what policy needs to be proposed, the study suggests the action of closing the widening gap between the ideal and the actual expectations of the ISPO criteria that are subjectively perceived by the smallholders. This research proposed a number of priority actions according to ISPO criteria. Some policies need to be formulated as follows: (1) speeding up the implementation land certification program fully admin- 
istered by land administration authorities; (2) holding training and education programs to enhance knowledge capacity of the smallholders in oil palm plantation management, as well as providing ready-to use technical assistance; (3) educating smallholders to be always aware of the environmental risks, such as land fire, that could be devastating to the environment; (4) facilitating the smallholders to establish supporting farming groups, assisting the smallholders in arranging business permits and licenses for all smallholders.

Author Contributions: This research-based article has been made possible through the collaborative work of several authors, where A.H.D. plays an important role in designing, conceptualization, writing, review, editing, as well as performing the analysis in this article. D.I.M. plays an important role in constructing methodology, coordinating data collection, investigation and validating data, as well as conducting IPA analysis of the paper. H.K. contributes significantly in reviewing and editing the paper. J.G. and P.P. play an important role in the supervision of this article. F.R., B.E.Y. and R.A. play the main role of field investigator, data collection, interviews and data visualization. All authors have read and agreed to the published version of the manuscript.

Funding: This work is supported by the Swiss National Science Foundation (grant numbers 400440 177587, 2018-2021).

Institutional Review Board Statement: Not Applicable.

Informed Consent Statement: Not Applicable.

Data Availability Statement: Not Applicable.

Acknowledgments: We would like to express our deep gratitude to the Swiss National Science Foundation (SNF) and to the Oil Palm Adaptive Landscape (OPAL) research project-a multi-year research project collaboration organized jointly between ETH-Zurich, the Center for International Forestry Research (CIFOR) and the Center for Agricultural and Rural Development Research of Bogor Agricultural University, Indonesia. We are also indebted to the oil palm farming households living in Muara Kaman Ulu (MKU) and Jonggon (JGN) villages as well as to various parties involved in a series of research interviews and fieldwork in Kutai Kartanagara, East Kalimantan, Indonesia.

Conflicts of Interest: We declare that there is no conflict of interest with regard to the publication of this research-based paper and no personal circumstance or interest that may be perceived as inappropriately influencing the representation or interpretation of reported research results. We also declare that the funder has no role in the design of the study; in the collection, analyses or interpretation of data; in the writing of the manuscript, or in the decision to publish this researchbased article.

\section{References}

1. Alonso-Fradejas, A.; Liu, J.; Salerno, T.; Xu, Y. The Political Economy of Palm Oil as Flex Crop. Transnational Institute (TNI) Agrarian Justice Program: Think Piece Series on Flex Crops \& Commodities. 2015. Available online: https://www.researchgate. net/publication/277710982 (accessed on 12 August 2020).

2. Borras, S.M. Foreword. In The Palm Oil Controversy in Shoutheast Asia: A Transnational Perspective; Pye, O., Bhattacharya, J., Eds.; Institute of Southeast Asian Studies Publishing: Singapore, 2013; ISBN 978-981-4311-45-8.

3. Purnomo, H.; Okarda, B.; Dermawan, A.; IIlham, Q.P.; Pacheco, P.; Nurfatriani, F.; Suhendang, E. Reconciling oil palm economic development and environmental conservation in Indonesia: A value chain dynamic approach. For. Policy Econ. 2020, 111, 102089. [CrossRef]

4. Krishna, V.V.; Kubitza, C. Impact of oil palm expansion on the provision of private and community goods in rural Indonesia. Ecol. Econ. 2020, 179, 106829. [CrossRef]

5. Rist, L.; Feintrenie, L.; Levang, P. The livelihood impacts of oil palm: Smallholders in Indonesia. Biodivers. Conserv. 2010, 19, 1009-1024. [CrossRef]

6. Mardiyaningsih, D.I.T.; Dharmawan, A.H.; Kolopaking, L.M.; Firdaus, M.; Nielsen, M.R. Livelihood transformation of rural communities: A livelihood system analysis of the Dayak Punan of Berau District, East Kalimantan, Indonesia. J. Econ. Sustain. Dev. 2018, 9. [CrossRef]

7. Kubitza, C.; Krishna, V.V.; Alamsyah, Z.; Qaim, M. The Economics Behind an Ecological Crisis: Livelihood Effects of Oil Palm Expansion in Sumatra, Indonesia. Hum. Ecol. 2018, 46, 107-116. [CrossRef] 
8. Colchester, M.; Chao, S. Ekspansi Kelapa Sawit di Asia Tenggara: Sebuah Tinjauan; Colchester, M., Chao, S., Dallinger, J., Sokhannaro, H.E.P., Dan, V.T., Villanueva, J., Eds.; Oil Palm Expansion in South East Asia: Trends and implications for local communities and indigenous peoples; FPP and SW: Bogor, Indonesia, 2011. Available online: https://www.forestpeoples.org/en/topics/palm-oilrspo/publication/2011/oil-palm-expansion-south-east-asia-trends-and-implications-loc (accessed on 13 August 2020).

9. Dharmawan, A.H.; Mardiyaningsih, D.I.; Komarudin, H.; Ghazoul, J.; Pacheco, P.; Rahmadian, F. Dynamics of Rural Economy: A Socio-Economic Understanding of Oil Palm Expansion and Landscape Changes in East Kalimantan, Indonesia. Land 2020, 9, 213. [CrossRef]

10. Adams, W.M. Green Development 3rd Edition: Environment and Sustainability in a Developing World; Routledge Taylor \& Francis Group: New York, NY, USA, 2009; ISBN 0-203-92971-3.

11. Amalia, R.; Dharmawan, A.H.; Prasetyo, L.B.; Pacheco, P. Perubahan Tutupan Lahan Akibat Ekspansi Perkebunan Kelapa Sawit: Dampak Sosial, Ekonomi dan Ekologi (Changes in Land Cover Due to Oil Palm Plantation Expansion: Social, Economic and Ecological Impacts). J. Ilmu Lingkung. 2019, 17, 130-139. [CrossRef]

12. Rulli, C.M.; Casirati, S.; Dell'Angelo, J.; Davis, K.F.; Passera, C.; D'Odorico, P. Interdependencies and telecoupling of oil palm expansion at the expense of Indonesian rainforest. Renew. Sust. Energ. Rev. 2019, 105, 499-512. [CrossRef]

13. Vijay, V.; Pimm, S.L.; Jenkins, C.N.; Smith, S.J. The Impacts of Oil Palm on Recent Deforestation and Biodiversity Loss. PLoS ONE 2016. [CrossRef]

14. Fitzherbert, E.B.; Struebig, M.J.; Morel, A.; Danielsen, F.; Bruhl, C.A.; Donald, P.F.; Phalan, B. How will oil palm expansion affect biodiversity? Trends Ecol. Evol. 2008, 23. [CrossRef]

15. Tarigan, S.D.; Sunarti-Widyaliza, S. Expansion of oil palm plantations and forest cover changes in Bungo and Merangin Districts, Jambi Province, Indonesia. Procedia Environ. Sci. 2015, 24, 199-205. [CrossRef]

16. Koh, L.P.; Wilcove, D.S. Is oil palm agriculture really destroying tropical biodiversity? Conserv. Lett. 2008, 1, 60-64. [CrossRef]

17. Saswattecha, K.; Kroeze, C.; Jawjit, W.; Hein, L. Improving environmental sustainability of Thai palm oil production in 2050. J. Clean. Prod. 2017, 147, 572-588. [CrossRef]

18. Pacheco, P.; Levang, P.; Dermawan, A.; Schoneveld, G. The Palm Oil Governance Complex: Progress, Problems and Gaps; CIFOR: Bogor, Indonesia, 2018. [CrossRef]

19. Abram, N.K.; Meijaard, E.; Ancrenaz, M.; Runting, R.K.; Wells, J.A.; Gaveau, D.; Pellier, A.S.; Mengersen, K. Spatially explicit perceptions of ecosystem services and land cover change in forested regions of Borneo. Ecosyst. Serv. 2014, 7, 116-127. [CrossRef]

20. Fedele, G.; Locatelli, B.; Djoudi, H. Mechanisms mediating the contribution of ecosystem services to human well-being and resilience. Ecosyst. Serv. 2017, 28, 43-54. [CrossRef]

21. Mol, H. The Politics of Palm Oil Harm: A Green Criminological Perspective; Springer Nature: Cham, Switzerland, 2017; ISBN 978-3-319-55378-8.

22. Yulian, B.E.; Dharmawan, A.H.; Soetarto, E.; Pacheco, P. Dilema nafkah rumahtangga pedesaan sekitar perkebunan kelapa sawit di Kalimantan Timur (Livelihood Dilemma of The Rural Household Around The Oil Palm Plantation in East Kalimantan). Sodality 2017, 5, 242-249. [CrossRef]

23. Amalia, R.; Dharmawan, A.H.; Putri, E.I.K. Perubahan lanskap ekologi dan resiliensi nafkah rumahtangga petani di sekitar hutan di Kalimantan Timur (Landscape Ecological Changes and Farm Household Livelihoods Resilience Around Forest In East Kalimantan). Sodality 2015, 3, 121-127. [CrossRef]

24. Euler, M.; Krishna, V.; Schwarze, A. Oil Palm Adoption, Household Welfare, and Nutrition Among Smallholder Farmers in Indonesia. World Dev. 2017, 93, 219-235. [CrossRef]

25. Koczberski, G.; Curry, G.N. Making a living: Land pressure and changing livelihood strategies among oil palm settlers in Papua New Guinea. Agric. Syst. 2005, 85, 324-339. [CrossRef]

26. Li, T.M. Social Impacts of Oil Palm in Indonesia: A Gendered Perspective from West Kalimantan; CIFOR: Bogor, Indonesia, 2015. [CrossRef]

27. Rahmadian, F.; Dharmawan, A.H.; Kinseng, R.A. Diskursus perizinan ekspansi perkebunan kelapa sawit: Studi kasus Kabupaten Kutai Kartanegara (Licensing Discourse of Oil Palm Expansion: Case Study of Kutai Kartanegara District). Sosiohumaniora 2020, 22, 114-124. [CrossRef]

28. Li, T.M. After the land grab: Infrastructural violence and the "Mafia System" in Indonesia's oil palm plantation zones. Geoforum 2018, 96, 328-337. [CrossRef]

29. Schmidt, J.; Rosa, M.D. Certified palm oil reduces greenhouse gas emissions compared to non-certified. J. Clean. Prod. 2020, 277. [CrossRef]

30. Higgin, V.; Richards, C. Framing sustainability: Alternative standards schemes for sustainable palm oil and South-South trade. J. Rural Stud. 2019, 65, 126-134. [CrossRef]

31. Astari, A.J.; Lovett, J.C. Does the rise of transnational governance 'hollow-out' the state? Discourse analysis of the mandatory Indonesian sustainable palm oil policy. World Dev. 2019, 117, 1-12. [CrossRef]

32. Junaedi, D. Prinsip dan kriteria Indonesian Sustainable Palm Oil (ISPO). In Proceedings of the Bingka Kaltim Workshop, East Kalimantan, Indonesia, 28 January 2021.

33. Schoneveld, G.C.; Haar, S.V.D.; Ekowati, D.; Andrianto, A.; Komarudin, H.; Okarda, B.; Jelsma, I.; Pacheco, P. Certification, good agricultural practice and smallholder heterogeneity: Differentiated pathways for resolving compliance gaps in the Indonesian oil palm sector. Glob. Environ. Chang. 2019, 57. [CrossRef] 
34. Saadun, N.; Lim, E.A.L.; Esa, S.M.; Ngu, F.; Awang, F.; Gimin, A.; Johari, I.H.; Firdaus, M.A.; Wagimin, N.I.; Azhar, B. Socioecological perspectives of engaging smallholders in environmental-friendly palm oil certification schemes. Land Use Policy 2018, 72, 333-340. [CrossRef]

35. Nesadurai, H.E.S. New Constellations of Social Power: States and Transnational Private Governance of Palm Oil Sustainability in Southeast Asia. J. Contemp. Asia 2017, 48, 204-229. [CrossRef]

36. Glasbergen, P. Smallholders do not Eat Certificates. Ecol. Econ. 2018, 147, 243-252. [CrossRef]

37. Hinkes, C.; Christoph-Schulz, I. Consumer Attitudes toward Palm Oil: Insights from Focus Group Discussions. J. Food Prod. Mark. 2019, 1-21. [CrossRef]

38. Giessen, L.; Burns, S.; Sahide, M.A.K.; Wibowo, A. From governance to government: The strengthened role of state bureaucracies in forest and agricultural certification. Policy Soc. 2016, 35, 71-89. [CrossRef]

39. Wiengarten, F.; Humphreys, P.; Onofrei, G.; Fynes, B. The adoption of multiple certification standards: Perceived performance implications of quality, environmental and health \& safety certifications. Prod. Plan. Control 2016, 28, 131-141. [CrossRef]

40. Gillespie, P. The Challenges of Corporate Governance in Indonesian Oil Palm: Opportunities to Move beyond Legalism? Asian Stud. Rev. 2012, 36, 247-269. [CrossRef]

41. Ivancic, H.; Koh, L.P. Evolution of sustainable palm oil policy in Southeast Asia. Cogent Environ. Sci. 2016, 2, 1-10. [CrossRef]

42. Martens, K.; Kunz, Y.; Rosyani, I.; Faust, H. Environmental Governance Meets Reality: A Micro-Scale Perspective on Sustainability Certification Schemes for Oil Palm Smallholders in Jambi, Sumatra. Soc. Nat. Resour. 2019, 1-17. [CrossRef]

43. Azzopardi, E.; Nash, R. A critical evaluation of importance-performance analysis. Tour. Manag. 2013, 35, 222-233. [CrossRef]

44. Martilla, J.A.; James, J.C. Importance-performance analysis. J. Mark. 1977, 41, 77-79. [CrossRef]

45. Oh, H. Revisiting importance-performance analysis. Tour Manag. 2001, 22, 617-627. [CrossRef]

46. Tyrrell, T.J.; Okrant, M.J. Importance-Performance analysis: Some recommendations from an economic planning perspective. Tour. Anal. 2004, 9, 63-76. [CrossRef]

47. Garrett, R.D.; Levy, S.; Carlson, K.M.; Gardner, T.A.; Godar, J.; Clapp, J.; Dauvergne, P.; Heilmayr, R.; le Polain de Waroux, Y.; Ayre, B.; et al. Criteria for Effective Zero-Deforestation Commitments. Glob. Environ. Chang. 2019, 54, 135-147. [CrossRef]

48. Pirker, J.; Mosnier, A.; Kraxner, F.; Havlik, P.; Obersteiner, M. What Are the Limits to Oil Palm Expansion? Glob. Environ. Chang. 2016, 40, 73-81. [CrossRef]

49. Ernah-Parvathi, P.; Waibel, H. Will teaching sustainability standards to oil palm smallholders in Indonesia pay off? Int. J. Agric. Sustain. 2020, 18, 196-211. [CrossRef]

50. Mc Carthy, J.F. Certifying in Contested Spaces: Private regulation in Indonesian forestry and palm oil. Third World Q. 2012, 33, 1871-1888. [CrossRef]

51. Jelsma, I.; Slingerland, M.; Giller, K.E.; Bijman, J. Collective action in a smallholder oil palm production system in Indonesia: The key to sustainable and inclusive smallholder palm oil? J. Rural Stud. 2017, 54, 198-210. [CrossRef]

52. McCarthy, J.F.; Gillespie, P.; Zen, Z. Swimming Upstream: Local Indonesian Production Networks in “Globalized" Palm Oil Production. World Dev. 2012, 40, 555-569. [CrossRef]

53. Macdonald, K. Private Sustainability standards as tools for empowering southern pro-regulatory coalitions? Collaboration, conflict and the pursuit of sustainable palm oil. Ecol. Econ. 2020, 167, 106-439. [CrossRef] 